\section{TREATMENT OF LIME IN THE EYE}

BY

\section{G. C. PETHER, M.D.}

\section{Honorary Physician, Devonshire Royal Hospital, Buxton}

In the industrial processes involved in the making of lime it is necessary to take precautions to minimize the injuries which may be caused by this substance. I have already described certain measures of a prophylactic nature that have proved valuable in the protection of the skin. In this paper procedures for dealing with lime in the eye will be discussed. Some of these may be carried out in the works.

\section{Early Measures}

Lime may enter the eye in the form of very fine dust or may also be in discrete particles, which have a marked tendency to adhere to its surface. It is of great importance in first-aid work that all large particles be removed as early as possible. This may be done with a spud, a fine needle, or other suitable instrument if the doctor is at once available to use it. In most cases, however, he is not near enough to the works to be able to deal immediately with such injuries. It is therefore necessary to place in the hands of the ambulance men such equipment as gives a reasonable prospect of success with little chance of further damage from injudicious use. For this reason ambulance men have been provided with camelhair brushes, which are smeared in a mixture of equal parts of liquid paraffin and vaselin. In the limestone country of Derbyshire climatic factors have to be kept in mind, the cold in winter being severe.

The mixture described is of such a consistency that it is neither too soft in summer nor too hard in winter. It facilitates the adhesion of small lime particles to the brush, and thus their removal. In some cases, where there is much spasm of the eyelids and photophobia with lacrimation, it is necessary to instil analgesic drops before any effective treatment can be begun. The large particles are then removed with the brush, if they can be detached from the surface of the eye without undue difficulty. The eye is then irrigated for several minutes with a warm solution from an undine. In the past boric acid solution or plain water has been popular, and all writers on this subject emphasize, and rightly, the value of free and prolonged irrigation. Before removal to hospital a little liquid paraffin is put in the eye, which is then covered with a pad and bandage or by an eye-shade as seems appropriate.

It has been observed that the folds of the upper and the lower lids are much less sensitive to the presence of lime, even if the particles are of considerable size, than is the globe of the eye. On many occasions men have reported to works medical officers complaining of slight discomfort in the eye of a few days' duration. Examination has then revealed fragments of considerable size in the folds of the upper or the lower lid, the history of the moment of entry being often vague.

A lime particle often attaches itself to the surface of the eye and, partly by chemical and partly presumably by thermal action, proceeds to burrow into the tissues. It may even become so completely sunken into these that only a small portion remains visible. When, in this manner, the surface layers have begun to close over it removal is extremely difficult. When seen in hospital or at the surgery the patient has usually received this first-aid treatment within the previous half-hour. It may suffice to verify the complete cleansing of the eye, or it may be necessary to set to work again to remove such particles as remain.

After a considerable experience of casualties of the type described I began to consider the possibility of improvement in treatment. Boric acid solutions were hallowed by usage, and it was also supposed that ammonium tartrate was very effective. In order to verify these impressions it appeared desirable to carry out some laboratory investigations. These were to determine the rate of solution of lime in different solvents which themselves should be incapable, as also any by-products formed in the process, of causing serious harm to the eye. A survey of the literature revealed that many substances had been used in the treatment of chemical eye injuries, but no exact inquiry into the rates of solution of lime appears to have been quoted.

\section{Nature of the Injury Caused by Lime}

The nature of the injury caused to the eye by lime has been a matter of dispute. Haurowitz and Braun (1922) have compared its action to that of alkaline solutions of strontium and barium. These produce a white clouding of the cornea. Other alkalis or magnesia did not bring about this effect under the same conditions, nor did neutral salts of the alkaline earths. They state that the opacity caused by lime is not due to an inorganic calcium compound, the only possible ones being the carbonate and phosphate, and these were definitely excluded. A calcium collagen compound was suspected, but they quote Mörner's experiments in which he removed the mucoid with $\mathrm{N} / 10$ ammonia. In such an eye, which contains only collagen, caustic lime caused no change of translucency. They were able to show that calcium was able to inhibit swelling, which power is also exerted in acid solutions. It is known that cartilage can remove calcium from calcium chloride solutions, and, since this occurs after the removal of mucoid, the opacity may be attributed to the formation of a calcium-collagen compound. It does not follow that such changes occur in the living eye. Furthermore, from experiments with the eye of a live rabbit it appeared that the lime content, while raised, returned to normal in four weeks, though the opacity persisted. It seems, then, that opacities are not due to lime-collagen compounds. Wolff (1926), however, describes particles of calcium carbonate in the cornea, which can be seen to become smaller during treatment with ammonium tartrate solution. Lime opacities are probably due to irreversible colloid changes in the mucoid, but the methods of estimating calcium in this are not delicate enough to permit exact analysis. The changes are, however, doubtless due to the calcium ions.

The reaction of lime with water may cause a rise of temperature to $300^{\circ} \mathrm{C}$., which suggests that the local production of heat is responsible, at least in part, for the damage done when lime particles enter the eye. The use of a Gradenigo thermometer has shown, however, that the temperature of the conjunctival sac as a whole is not raised. Alajmo (1929) has supported the findings of Haurowitz and Braun, and states that the turbidity of the cornea is possibly due to the $\mathrm{OH}$ ion and the associated $\mathrm{Ca}$ ion. The action of the $\mathrm{OH}$ ion in causing swelling and liquefaction is common to all alkalis, though the opacities such as are seen with lime do not occur to the same degree with other substances of this kind. 


\section{Solvents at Present in Use}

Since the salts of heavy metals have a precipitating action on protein particles from adsorption of the cation it would appear that, following the laws of chemical equilibrium, these changes should be reversible. Antonibon (1931) suggests that improvement in an established opacity is inevitably associated with the combining of the calcium in an insoluble form or in a soluble one which is but little dissociated. Alajmo had advised the use of trisodium citrate, and his favourable impressions of this, in an 8 per cent. solution, were confirmed by Antonibon, who made experiments with rabbits, using both 10 per cent. ammonium tartrate and 8 per cent. trisodium citrate. As a control one eye was irrigated with saline a minute after the lime had entered. Later on Antonibon made similar observations in man, irrigations lasting five to ten minutes being carried out four or five times a day. Opacities of different ages and of varying degree were treated. The small corneal lesions healed perfectly, no trace being detectable with the slit-lamp. In these tests the superiority of trisodium citrate as compared with neutral ammonium tartrate was very evident. Ionization with trisodium citrate has also been tried by Antonibon and likewise by Grósz (1935), who used ammonium tartrate in the same way. The results were somewhat conflicting. Other solutions that have been used in the treatment of lime in the eye are weak acetic acid, picric acid, glucose, and ammonium acetate. There is necessarily some evolution of heat when any of these come into contact with lime, and in the case of the glucose solutions the heat evolved was found to be a definite contraindication to further trial.

From what has been stated it is clear that there was need for further analytical work to determine the properties of the various possible solvents. Such work was undertaken on my behalf in the Buxton laboratories of Imperial Chemical Industries, from which the following report was issued.

\section{Solubility of Lime in Neutral Salt Solutions}

In order to obtain conditions similar to those occurring in eye treatment the apparatus used consisted of a sintered glass crucible (size I.G.3) connected to a Buchner flask, and suction was applied in each case so that the solution washed over the lime on the filter of the crucible and passed through into the flask. The lime used throughout was prepared by crushing a lump of light-burnt reactive lime to pass a one-eighth inch mesh and be retained on a sixteenth inch mesh. Since 1 gramme of lime was employed in each test the surface of lime exposed for attack was approximately the same throughout. The solutions used were such that 1 litre of each solution was capable of dissolving half a gramme-molecule of $\mathrm{CaO}$-that is, the solutions had the same dissolving power with regard to lime. Borax was the exception, since the low solubility of this substance prevented the preparation of the standard strength solution.

A burette of $100 \mathrm{ml}$. capacity, having a glass nozzle attached by rubber tubing closed by a pinch-cock, was clamped above the crucible, etc., so that the distance between the end of the nozzle and the top of the filter was two inches. Using this standard apparatus the procedure was as follows. One gramme of the prepared lime was spread uniformly over the surface of the filter in the crucible, and $100 \mathrm{ml}$. of the salt solution from the burette (with the pinch-cock full open) was run over the lime, the suction being adjusted as mentioned above. The filtrate was transferred to a beaker and the lime dissolved was determined by the oxalate method. The results obtained are given in Table $I$.

The figures for $\mathrm{gm}$. $\mathrm{NH}_{3}$ produced or $\mathrm{gm}$. $\mathrm{NaOH}$ produced are the theoretical values calculated from the equation of the
TABLE I.-Solubility of Lime in Various Salt Solutions. (Volume of solution used, $100 \mathrm{ml}$. Rate of addition of solution: $100 \mathrm{ml} . / 33$ seconds-that is, $182 \mathrm{ml}$./min.)

\begin{tabular}{|c|c|c|c|c|c|c|c|c|}
\hline Substance & $\begin{array}{l}\text { Molar } \\
\text { Soln. }\end{array}$ & $\begin{array}{c}\% \\
\text { Soln. } \\
\text { w/v. }\end{array}$ & $\begin{array}{l}\mathrm{Gm} . \\
\mathrm{CaO} \\
\text { Diss. }\end{array}$ & $\begin{array}{c}\mathrm{Gm} . \\
\mathrm{NH}_{3} \\
\text { Prod. }\end{array}$ & $\begin{array}{c}\text { Gm. } \\
\mathrm{CaO} \\
\text { Diss. } \\
\text { perMin. }\end{array}$ & $\begin{array}{c}\% \\
\text { Effi- } \\
\text { ciency }\end{array}$ & $\begin{array}{c}\text { Rela- } \\
\text { tive } \\
\text { Value* }\end{array}$ & $\begin{array}{l}\text { Time } \\
\text { Value }\end{array}$ \\
\hline Ammon.chloride & $\mathbf{M}$ & 5.3 & 0.1243 & 0.0755 & 0.2260 & 4.4 & 14.8 & 1.0 \\
\hline tartrate & $\mathbf{M} / 2$ & 9.2 & 0.0416 & 0.0253 & 0.0756 & 1.5 & 5.0 & 3.0 \\
\hline " acetate & $\mathbf{M}$ & 7.7 & 0.0409 & 0.0248 & 0.0744 & 1.5 & 4.9 & 3.0 \\
\hline " citrate & $\mathbf{M} / 3$ & 8.1 & 0.0364 & 0.0221 & 0.0662 & 1.3 & 4.3 & 3.4 \\
\hline Sodium citrate & $\mathbf{M} / 3$ & 8.6 & 0.0330 & $0.0356 \ddagger$ & 0.0600 & 1.2 & 3.9 & 3.8 \\
\hline Boric acid & $\mathbf{M} / 3$ & 2.1 & 0.0109 & 一 & 0.0198 & 0.4 & 1.3 & 11.4 \\
\hline Borax .. & $\mathrm{M} / 6$ & Sat. & 0.0070 & $0.0076 \ddagger$ & 0.0127 & 0.7 & 0.8 & 17.8 \\
\hline Distilled water & 一 & 一 & 0.0084 & 一 & 0.0144 & 4.9 & 1.0 & 14.8 \\
\hline
\end{tabular}

* Solution value, relative to water. † Time of dissolving, relative to ammonium chloride. $\ddagger \mathrm{Gm}$. NaOH produced.

reaction, and really represent the percentage solution of $\mathrm{NH}_{3}$ or $\mathrm{NaOH}$ which the eye must suffer during the treatment The percentage of efficiency is 100 times the amount of $\mathrm{CaO}$ dissolved divided by the theoretical amount of $\mathrm{CaO}$ which $100 \mathrm{ml}$. of the solution is capable of dissolving in unlimited time, and disregarding the solubility of the product of the reaction. It is evident that ammonium chloride is much superior to any of the other salts tested. It dissolves 14.8 times the amount of $\mathrm{CaO}$ dissolved by water, or water takes 14.8 times the length of time that $\mathrm{NH}_{4} \mathrm{Cl}$ takes to dissolve equal quantities of lime.

In view of the above results the solubility of lime in different strengths of $\mathrm{NH}_{4} \mathrm{Cl}$ solution was determined. In this case the procedure was slightly altered. The solution passing through the filter was led through known quantities of standard hydrochloric acid, some of which combined with the $\mathrm{NH}_{3}$ evolved during the reaction. The excess acid was titrated with standard alkali and the amount of $\mathrm{CaO}$ dissolved calculated. This quick method was found to give results comparable to the oxalate method. The results are given below.

TABLE II.-Solubility of Lime in $\mathrm{NH}_{4} \mathrm{Cl}$ Solutions of Different Strengths. (Volume of solution used, $100 \mathrm{ml}$. Rate of addition of solution: $100 \mathrm{ml} . / 33$ seconds-that is, $182 \mathrm{ml} . / \mathrm{min}$.)

\begin{tabular}{c|c|c|c|c}
\hline $\begin{array}{c}\text { \% NH.Cl } \\
\text { Solution }\end{array}$ & $\begin{array}{c}\text { Gm. CaO } \\
\text { Dissolved }\end{array}$ & $\begin{array}{c}\text { Gm. NH } \\
\text { Produced }\end{array}$ & $\begin{array}{c}\text { Gm. CaO } \\
\text { Diss. per Min. }\end{array}$ & $\begin{array}{c}\% \\
\text { Efficiency }\end{array}$ \\
\cline { 1 - 4 } & 0.1317 & 0.0799 & 0.2397 & 5.0 \\
4 & 0.1143 & 0.0694 & 0.2080 & 5.5 \\
3 & 0.0881 & 0.0535 & 0.1623 & 5.6 \\
2 & 0.0652 & 0.0396 & 0.1187 & 6.2 \\
1 & 0.0334 & 0.0203 & 0.0608 & 6.4 \\
\hline
\end{tabular}

These results indicate practically a straight-line reduction in solubility, and that a 1.2 per cent. solution of $\mathrm{NH}_{4} \mathrm{Cl}$ dissolves as much $\mathrm{CaO}$ as a 9.2 per cent. solution of ammonium tartrate, which was next best.

In order to determine the effect of rate of flow of solution on the solubility, experiments were carried out using a 1 per cent. solution of $\mathrm{NH}_{4} \mathrm{Cl}$ (since it was indicated that 1 per cent. saline solutions are approximately isotonic with eye fluid) and different nozzles on the burette. The results are given in Table III.

TABLE III.-Solubility of Lime in 1 per cent. $\mathrm{NH}_{4} \mathrm{Cl}$ Solution at Different Rates of Addition. (Volume of 1 per cent. solution used, $100 \mathrm{ml}$.)

\begin{tabular}{c|c|c|c|c|c}
\hline $\begin{array}{c}\text { Time of Flow } \\
\text { (sec./100ml.) }\end{array}$ & $\begin{array}{c}\text { Rate of Flow } \\
\text { (ml./min.) }\end{array}$ & $\begin{array}{c}\text { Gm. CaO } \\
\text { Dissolved }\end{array}$ & $\begin{array}{c}\text { Gm. } \mathrm{NH}_{3} \\
\text { Produced }\end{array}$ & $\begin{array}{c}\text { Gm. CaO } \\
\text { Diss. per Min. }\end{array}$ & $\begin{array}{c}\% \text { Effici } \\
\text { ency }\end{array}$ \\
\hline 68 & 88 & 0.0491 & 0.0298 & 0.0434 & 9.4 \\
33 & 182 & 0.0334 & 0.0203 & 0.0608 & 6.4 \\
20 & 300 & 0.0261 & 0.0158 & 0.0783 & 5.0 \\
\hline
\end{tabular}


The effect of $\mathrm{NH}_{4} \mathrm{Cl}$ solution on limestone was also tried. Since it was expected that the rate of solution would be too slow to be measured in the above apparatus, 1 gramme of limestone crushed to pass a No. 14 B. S. sieve, and be retained on a No. 25 B. S. sieve, was mixed with $100 \mathrm{ml}$. of solution and allowed to stand for four hours, after which the lime dissolved was determined. The results obtained were:

$$
\begin{array}{cccccccc}
\multicolumn{2}{c}{\text { Solution Used }} & & & \multicolumn{3}{c}{\mathrm{Gm} .} & \mathrm{CaCO}_{3} \\
1 \% \text { Ammonium } & \text { chloride } & . . & \ldots & . . & . . & 0.0262 \\
9.2 \% & \text { t } & \text { tartrate } & . . & . . & . & \ldots & 0.0393
\end{array}
$$

Assistance was also obtained from the pathological laboratory of the Devonshire Royal Hospital, from which the following report was received.

Experiment 1.-Rough time-dilution curve (see chart) for complete lysis of one drop of blood by $1 \mathrm{c.cm}$. of differing

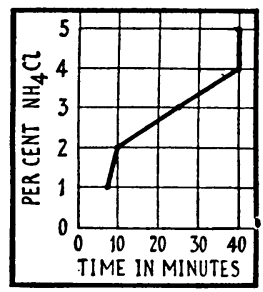

concentrations of ammonium chloride solutions at $37^{\circ} \mathrm{C}$. The curve suggests that two factors are operating-possibly hypotonicity in the low concentrations and acidity in the high ones.

Experiment 2.-A guinea-pig received ten drops of normal saline into the right eye and seven drops of 3 per cent. ammonium chloride solution (made with distilled water) into the left-both solutions at $37^{\circ} \mathrm{C}$. The ammonium chloride obviously caused some smarting: the animal resisted it, but not the irrigation with saline. The eye was examined at intervals during the next two hours and showed no difference from the right eye. There was no trace of inflammation. Two days later the animal was killed for tubercle diagnosis. Both eyes were perfectly normal.

\section{Encouraging Results with Ammonium Chloride}

I then tried the effect of a 4 per cent. solution of ammonium chloride in my own eye, and found that it caused less smarting than did the solution of boric acid normally employed. Ridley gives a figure of $0.551^{\circ} \mathrm{C}$. for the depression of the freezing-point of tears, and, calculated from this, tears would be isotonic with 0.85 per cent. $\mathrm{NH}_{4} \mathrm{Cl}$. In view of the good tolerance exhibited to stronger solutions it did not, however, appear necessary to adhere to this strength. A 4 per cent. solution of ammonium chloride was then issued to a few works for trial, the ambulance attendants being instructed to present their reports after one month. These have now been received, and are sufficiently encouraging to justify more extensive use. It has been noted that the solution tends to grow moulds if kept too long. For this reason one may add to a Winchester bottle a small quantity of preservative.

The casualties from lime burns of the eye, after transfer from the works, are treated in the local hospital. Here also the ammonium chloride solution has been used immediately subsequent to any instrumental intervention that may be needed. It is possible that the addition of a small proportion of an analgesic to the irrigating fluid might be helpful, but this will have to be tried at a later date. The removal of lime particles with an instrument is usually impossible until the eye has been anaesthetized. Moss (1936) has pointed out that $\frac{1}{2}$ per cent. decicaine, which is neutral, is less painful when instilled than cocaine or butyn, which are acid in solution. It must be understood that treatment on the lines described may require supplementing by those measures which are usual when gross ulceration has occurred. It should be pointed out, however, that treatment with ammonium chloride solution need not be restricted to the first irrigation or even to the first twenty-four hours. The solution may usefully be employed even beyond this time.

When starting this work I was aware that ammonium chloride had been used in the treatment of various alkali burns of the eyes. It appeared to me somewhat surprising that little emphasis has been placed on the peculiar advantages of this solution in the treatment of lime injuries, for it is in these especially that it is most valuable.

\section{Summary}

The power of various neutral solutions to dissolve lime has been calculated by a series of experiments. It is shown that ammonium chloride is more effective than any solutions which have hitherto been generally employed. This solution in 4 per cent. strength has been tried out on a series of cases with considerable success. It is no more painful to the eye than other irrigating fluids. The preliminary application of an analgesic solution and the removal of large particles by means of a camel-hair brush dipped in a mixture of vaselin and paraffin should also form part of the first-aid treatment.

I wish to express my thanks to Mr. J. H. Gilfillan, who so kindly organized the tests made in the I.C.I. laboratories. I am also nuch indebted to Dr. G. L. Robinson, who made the other investigations described.

\section{BIBLIOGRAPHY}

Alajmo, B. (1929). Boll. Oculist., 8, 827

Antonibon, A. (1931). Ibid., 10, 316.

Barkan, O., and Barkan, H. (1924). J. Amer. med. Ass., 83, 1567. Fortunati, A. (1907). Ann. Ottalm., 36, 746.

Grósz, I. (1935). Szemészet, 70, 268. Abstract in Zbl. ges. Ophth., 1935-6, 35, 193.

Haurowitz, F., and Braun, G. (1922). Hoppe-Seyl. Z., 123, 79. McAndrews, L. F. (1932). Arch. Ophthal., 7, 779.

Moss, O. W. (1936). New Orleans med. surg. J., 89, 302.

Ruedemann, A. D. (1936). Surg. Clin. N. Amer., 16, 979.

Stroschein, E. (1892). Z. ärztl. Landpraxis, 1, 148.

Stutzer, H. G. (1900). Disch. med. Wschr., 26, 594.

Wolf, E. (1926). Brit. J. Ophthal., 10, 196.

Würdemann, H. V. (1932). Injuries of the Eye, St. Louis.

The annual reports of the Medical Departments, Straits Settlements and Federated Malay States, for the year 1937 have just been published (Government Printing Office, Singapore, 2s. 4d.). Three races predominate in Malaya-Malays, Chinese, and Indians-and the statistics given in these reports are of especial interest when analysed by race, a point to which attention was drawn in these columns recently by Dr. I. D. Gebbie (March 4, p. 438). Thus throughout the whole area the number of maternal deaths per 1,000 live births varies from seven to ten. Among the Chinese, however, the rate is as low as 3.6 per 1,000 live births in some regions. The corresponding figure for Malays is 13 per 1,000 and for Indians in the Singapore municipal area 24.35 per 1,000 . "Unhealthy traditional customs and faulty nutrition" are blamed for this high mortality. The number of lepers in settlements in Malaya at the end of 1937 was 3,807, and there were 4,494 patients in mental hospitals, most of whom were Chinese or Indian. In the Straits Settlements new cases applying for treatment for all forms of venereal disease represent 145 per 10,000 population. This does not allow for the garrison at Singapore or for patients treated privately, and should be compared with 9.8 per 10,000 , which is the corresponding figure for England. 